\title{
New data on sauropod palaeobiodiversity at the Jurassic-Cretaceous transition of Spain(Burgos)
}

\author{
F. Torcida Fernández-Baldor ${ }^{1}$ D $\cdot$ J. I. Canudo ${ }^{2}$ D $\cdot$ P. Huerta ${ }^{1,3}$ (D)
}

Received: 4 March 2020 / Accepted: 27 October 2020

(c) Universidad Complutense de Madrid 2020

\begin{abstract}
The present paper studies a humerus (MDS-VPCR, 214) recovered from the site of Valdepalazuelos-Tenadas del Carrascal (Burgos, Spain). Geologically, it is located at the base of the Rupelo Formation (Cameros Basin), which is Tithonian-Berriasian in age. This formation is interpreted as shallow lacustrine/palustrine deposits with low-gradient margins and periodic changes in the water level. MDS-VPCR, 214 is gracile and straight, and has a larger mediolateral expansion at its proximal end than at the distal end. The deltopectoral crest is well expanded anteroposteriorly and extends towards the midline of the shaft. The distal articular head has radial and ulnar condyles similar in degree of development and there is a narrow groove between them. The distal articular surface is not divided between the ulnar and radial condyles; this surface extends towards the anterior and posterior surfaces of the humerus. MDS-VPCR, 214 shows significant morphological differences with respect to the humeri of the Iberian sauropods of the Jurassic-Cretaceous transition such as the turiasaurians Losillasaurus, Zby and Turiasaurus, the basal macronarians Lourinhasaurus and Aragosaurus, and the titanosauriforms Lusotitan, Galvesaurus. A phylogenetic analysis of MDS-VPCR, 214 relates it to Titanosauriformes probably a basal brachiosaurid related with the english genus of Kimmeridgian Duriatitan. Therefore MDS-VPCR, 214 is assigned provisionally to aff. Duriatitan.
\end{abstract}

Keywords Jurassic-Cretaceous transition $\cdot$ Humerus $\cdot$ Sauropoda $\cdot$ Titanosauriformes $\cdot$ Palaeobiodiversity $\cdot$ Spain

\section{Resumen}

Se estudia un húmero (MDS-VPCR, 214) recuperado en el yacimiento Valdepalazuelos-Tenadas del Carrascal (Burgos, Spain). Geológicamente se sitúa en la base de la Formación Rupelo (Cuenca de Cameros) de edad Titoniense - Berriasiense. Esta formación se interpreta como depósitos lacustres-palustres con márgenes de bajo gradiente y cambios periódicos en el nivel del agua. MDS-VPCR, 214 es grácil y recto, presentando una mayor expansión mediolateral en el extremo proximal respecto al distal. La cresta deltopectoral está bien expandida anteroposteriormente y se extiende hacia la línea media de la diáfisis. La cabeza articular distal presenta en la superficie anterior los cóndilos radial y ulnar, de desarrollo semejante, y que dejan entre ellos un estrecho surco. La superficie articular distal no está dividida entre los cóndilos ulnar y radial; esta superficie se extiende hacia las superficies anterior y posterior del húmero. MDS-VPCR, 214 presenta diferencias morfológicas significativas con los húmeros de los saurópodos ibéricos del tránsito Jurásico - Cretácico como son los turiasaurianos Losillasaurus, Zby y Turiasaurus, los macronarios basales Lourinhasaurus y Aragosaurus y los Titanosauriformes Lusotitan y Galvesaurus. Un análisis filogenético del MDS-VPCR, 214 lo relaciona con Titanosauriformes,

F. Torcida Fernández-Baldor

fideltorcida@hotmail.com

J. I. Canudo

jicanudo@unizar.es

P. Huerta

phuerta@usal.es

1 Museo de Dinosaurios de Salas de los Infantes and Colectivo Arqueológico-Paleontológico Salense (CAS), Plaza Jesús Aparicio 9, 09600 Salas de los Infantes, Burgos, Spain
2 Grupo Aragosaurus-IUCA, Paleontologia, Facultad de Ciencias, Universidad de Zaragoza, C/Pedro Cerbuna, 12, 50009 Zaragoza, Zaragoza, Spain

3 Departamento de Geología, Escuela Politécnica Superior de Ávila, Universidad de Salamanca, Salamanca, Spain 
probablemente un braquiosáurido basal afín a Duriatitan, un género inglés del Kimmeridgiense. Por esta razón, MDS-VPCR, 214 se asigna provisionalmente a aff. Duriatitan.

Palabras Clave Tránsito Jurásico-Cretácico $\cdot$ húmero $\cdot$ Sauropoda $\cdot$ Titanosauriformes $\cdot$ paleobiodiversidad $\cdot$ España

\section{Introduction}

The sauropods at the end of the Jurassic (KimmeridgianTithonian) and the beginning of the Cretaceous (Berriasian) in the Iberian Peninsula (Spain and Portugal) have a singular and diverse record (Canudo et al. 2006; Royo-Torres et al. 2009; Mocho et al. 2017). The known sauropod record includes taxa from basal Macronaria, Titanosauriformes, Diplodocoidea and Turiasauria. Nine taxa have been described so far: Turiasaurus, Losillasaurus, Zby, Dinheirosaurus, Galvesaurus, Lusotitan, Lourinhasaurus, Oceanotitan and Aragosaurus. There is also various material not assigned to a specific taxon (Royo-Torres et al. 2009; Canudo et al. 2010; Mocho et al. 2019 and references). The Portuguese sauropods recovered in the Upper Jurassic-Lower Cretaceous sequence were deposited during the third rifting episode of the Lusitanian Basin (Kullberg et al. 2006). The Spanish sauropods described from the JurassicCretaceous transition were recovered exclusively from the Iberian Maestrazgo Basin (Aurell et al. 2019; Campos-Soto et al. 2019) and the stratigraphy has been modified using various nomenclatures (Platt 1986; Clemente and Pérez Arlucea 1993; Martín-Closas and Alonso Millán 1998; Arribas et al. 2003; Clemente 2010; Mas et al. 2019). One of these is the Cameros Basin, where a fragmentary record of sauropod fossil bones is known (Canudo et al. 2010). The record of sauropod footprints here is abundant and diverse, and has been used in projects of geotourism (Torcida FernándezBaldor et al. 2012; Castanera et al. 2018).

Recently, a complete sauropod humerus has been recovered from the Jurassic-Cretaceous boundary of the Cameros Basin. The fossil is from the site of Valdepalazuelos-Tenadas del Carrascal in the western part of the Cameros Basin, close to the village of Torrelara in Burgos, Spain (Fig. 1). Remains of two different sauropod individuals and isolated teeth of theropods have been identified in the initial excavations. This site is located near the mega-site of Las Sereas, where abundant sauropod tracks and other dinosaur tracks are conserved at the top of Rupelo Fm. (Torcida FernándezBaldor et al. 2012).

The humeri of the sauropod taxa described from the Jurassic-Cretaceous boundary of the Iberian Peninsula are all known apart from those belonging to the diplodocoid Dinheirosaurus and the titanosauriform Oceanotitan. This allows for a precise comparison of the humerus from Valdepalazuelos with those from the taxa that have been described. Accordingly, the aim of this paper is to describe the humerus from Valdepalazuelos and to ascertain its phylogenetic position.

\section{Geological setting}

From a geological point of view, the site of Valdepalazuelos is located within the Mesozoic succession of the Cameros Massif (Fig. 1). This massif was an extensional basin, located in the northwestern sector of the Iberian rift during the Upper Jurassic-Lower Cretaceous period. Several authors have worked on the western part of the Cameros Basin since the 1960s, and the stratigraphy has been modified using various nomenclatures (Platt 1986; Clemente and Pérez Arlucea 1993; Martín-Closas and Alonso Millán 1998; Arribas et al. 2003; Clemente 2010). From a stratigraphic point of view, the site of Valdepalazuelos is located in the transition between the Las Viñas and the Ladera Member within the Rupelo Formation (Fig. 1b), according to the terminology of Platt (1986). Following the terminology of Clemente and Pérez Arlucea (1993), the site is located in the transition between the Señora de los Brezales Fm. and the Boleras Fm. The Cameros Basin succession in this area lies unconformably on Jurassic marine limestones. It consists of a clastic stage (Stage 1), mainly composed of conglomerates, sandstones and red mudstones, which is overlain by a carbonate-dominated stage (Stage 2), mainly calcretes, and palustrine and lacustrine limestones (Sacristán-Horcajada et al. 2015). The age of these units is Tithonian-Berriasian, according to the charophyte and ostracod biostratigraphy (Martín-Closas and Alonso Millán 1998; Schudack and Schudack 2009). Recently, the upper part of the Rupelo Fm. has been assigned to the Berriasian (San Marcos Fm.) (Mas et al. 2019), but Valdepalazuelos site, which locates at the base of Rupelo Fm. in Torrelara is considered by the same authors as Tithonian (Boleras Fm.) (Sacristán-Horcajada et al. 2015).

The site of Valdepalazuelos is constituted by a 2 m-thick grey marl bed that contains numerous vertebrate bones. Calcite nodules are widespread in the bed and some contain bone fragments in their core. The bones are covered by a millimetric grey micrite crust, and charcoal and leaf fragments are common. Jurassic limestone pebbles are scattered within the marl bed. Overlying the site bed, the marls show red to orange mottling arranged in vertical structures and slicken sides. Carbonate nodules reach decimetric sizes and become more abundant 
(a)

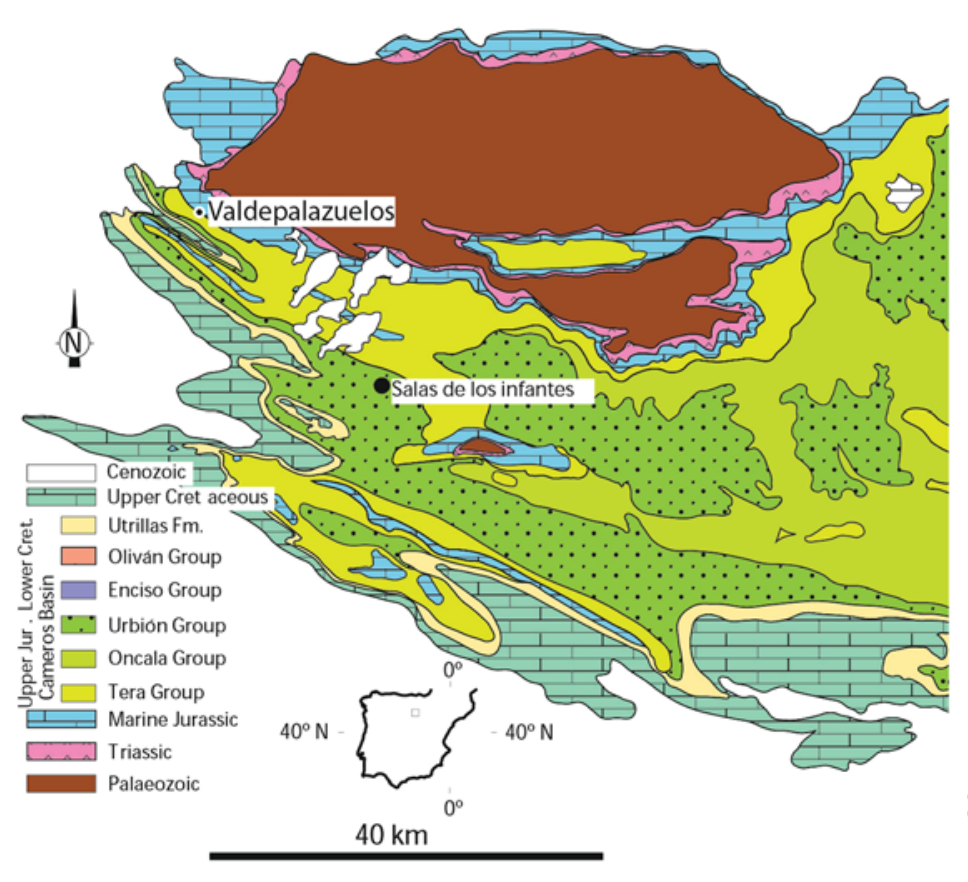

(b)

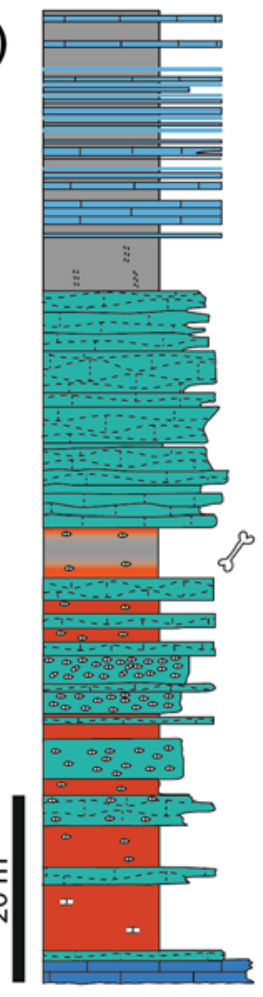

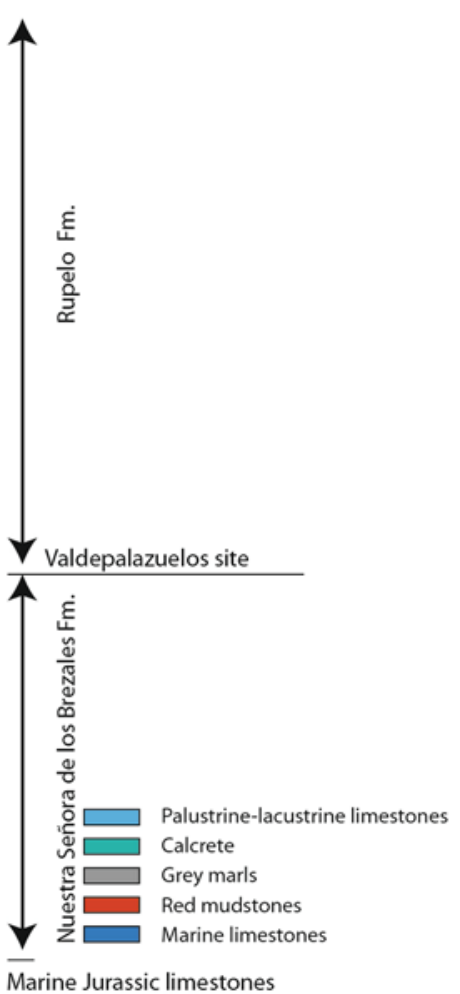

Fig. 1 Geological setting of Valdepalazuelos site. a Geological map of western Cameros basin, based on Beuther (1966). b Sketch of the Valdepalazuelos section

upwards, as the carbonate content increases towards a well-developed calcrete with prismatic structures. The carbonate content increases upwards towards a welldeveloped calcrete with prismatic structures. According to the evidence from previous sedimentological research on the above-mentioned units, the site of Valdepalazuelos developed in the transition from distal alluvial deposits to palustrine-lacustrine environments (Platt 1989; SacristánHorcajada et al. 2015). This transition is commonly dominated by a calcrete fringe (Alonso-Zarza 2003; Huerta and Armenteros 2005). The site is interpreted as a ponded area located within the alluvial-calcrete fringe transition. The sediment recorded anoxic conditions, as is evidenced by the charcoal and carbonized leaf fragments.

\section{Materials and methods}

\section{Institutional abbreviations}

MDS: Museo de Dinosaurios (Salas de los Infantes, Burgos, Spain).

VPCR: Yacimiento de Valdepalazuelos- Tenadas del Carrascal.
MDS-VPCR, 214 was recovered in 2018 during excavation campaigns undertaken by the Colectivo Arqueológico y Paleontológico de Salas de los Infantes, with the corresponding notification of the Heritage Office of the Regional Government of Castilla y León. The material recovered is housed in the Museo de Dinosaurios de Salas de los Infantes (Salas de los Infantes, Burgos, Spain).

In general, we use the standardized anatomical nomenclature based on the Nomina Anatomica Avium and Nomina Anatomica Veterinaria (see Harris 2004). The eccentricity of the shaft of the humerus was calculated in accordance with Otero (2010) and Mannion et al. (2013). The identification and nomenclature of the muscular insertions are based upon the papers by Borsuk-Bialynicka (1977) and Otero (2018). The calculation of the depth of the anconeal fossa follows Upchurch et al. (2015).

Taxonomic abbreviations

In designing the figures, various taxonomic abbreviations were used. CBB, coracobrachialis brevis; DSC, scapular deltoid; LD, latissimus dorsi; ADM, anterodistal muscles; LDM, laterodistal muscles; MDM, mediodistal muscles; PDM, posterodistal muscles; P, pectoral; SBSC, subcoracoscapularis; SCHA, scapulohumeralis anterior; SUC, 
supracoracoideus; TBL, triceps brachii caput laterale; TBM, triceps brachii caput medialis.

Anatomical structures: DPC, deltopectoral crest; $\mathrm{HH}$, humeral head; AF, anconeal fossa.

Parameters and indices of the dimensions of the humerus (Table 1). APWS: anteroposterior width shaft; LDPC: length deltopectoral crest; ECC: eccentricity index; L: total length; MLWDE: mediolateral width distal end; MLWPE: mediolateral width proximal end; MLWS: mediolateral width shaft; DPEADPC: distance from proximal end to apex of deltopectoral crest. RI, robustness index. GI, Gracility index: MLWDE/L and MLWPE/L (Barco 2009).

\section{Systematic palaeontology}

Saurischia Seeley, 1887

Sauropoda Marsh, 1878

Neosauropoda Bonaparte, 1986

Titanosauriformes Salgado, Coria and Calvo, 1997

Brachiosauridae ? Riggs, 1904

\section{Aff. Duriatitan}

\subsection{Description}

MDS-VPCR, 214 is an almost complete right humerus, preserved in two parts, with a small part of the shaft missing (Fig. 2). The proximal part of the shaft is fractured by a small break that displaced the two parts of the shaft roughly $37 \mathrm{~cm}$ at the site. The fracture plane show a series of cracks curved towards the inner part of the bone and proximally, and with a small part of the shaft missing, which prevents the two bone fragments from joining perfectly. The proximal half of the shaft in the fracture area has scarcely undergone any deformation.

The overall shape of MDS-VPCR, 214 is straight in lateral and anterior view, as is usually the case with the sauropod humerus (Upchurch et al. 2004). In anterior view, the proximal end is gently expanded mediolaterally, and the distal end is slightly expanded medially (Fig. 2a). The proximal end is more expanded mediolaterally than the distal (the ratio between them is 1.4 ; see Table 1 ). The two ends are twisted such that they are not in the same plane.

MDS-VPCR, 214 is a gracile humerus, with an RI value of 0.25 (following Wilson and Upchurch 2003; see Table 1). The estimated values of the ratio between the width of the proximal and distal ends and the total length of the humerus are 0.34 and 0.25 respectively (Table 1). Two tendencies have been described in sauropods with respect to this character (Barco 2009), starting from a robust humerus in the majority of sauropods. The first tendency is an increase in robustness due to greater lateromedial

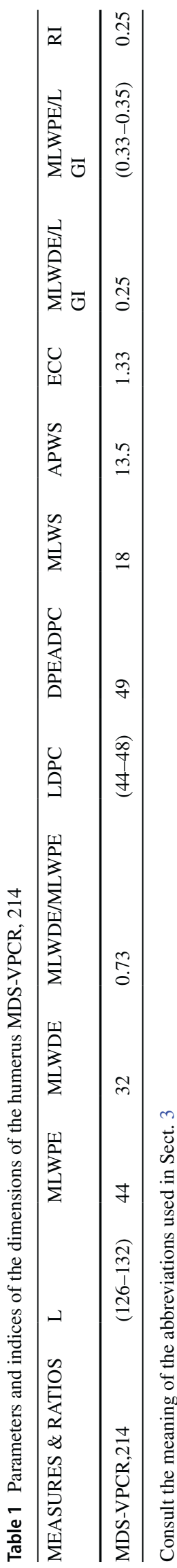




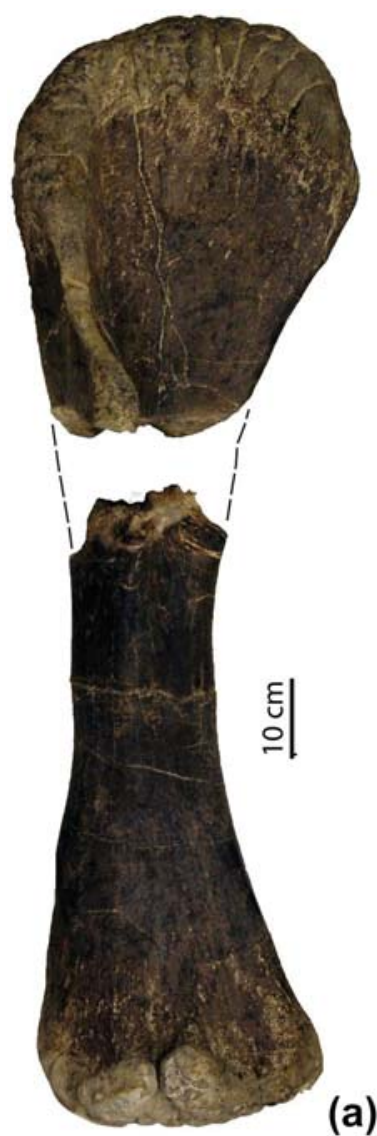

(a)

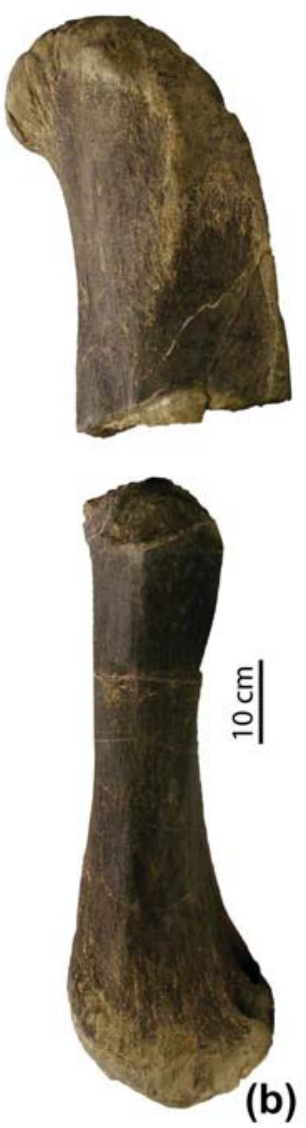

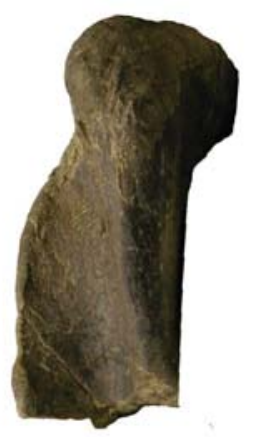

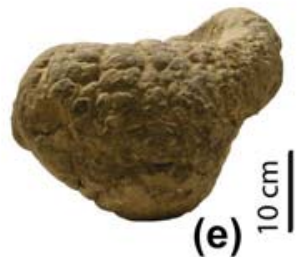

(e)
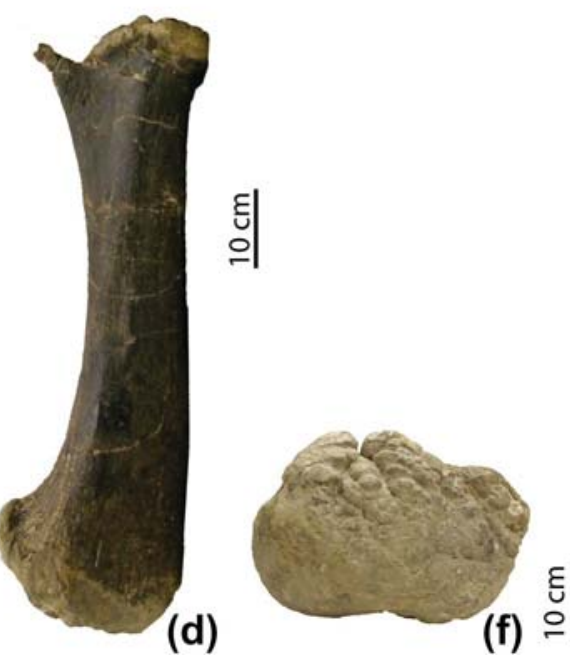

(c)

Fig. 2 Humerus MDS-VPCR, 214. a Anterior view; b lateral view; c posterior view; $\mathbf{d}$ medial view; e proximal view; $\mathbf{f}$ distal view. Scale $10 \mathrm{~cm}$

expansion at both ends, roughly $40 \%$ proximally and $50 \%$ distally. This is convergently present in basal macronarians such as Camarasaurus, diplodocoids such as Suuwassea and in titanosaurians (Osborn and Mook 1921; Ostrom and McIntosh 1966; Borsuk-Bialynicka 1977; Harris 2007; Hocknull et al. 2009; Otero 2010). The second tendency is an increase in gracility, with values of less than $30 \%$ proximally and $25 \%$ distally, as recorded in brachiosaurids (Janensch 1961; Mannion et al. 2013, 2017; Royo-Torres et al. 2017). MDS-VPCR, 214 shows high gracility, with values similar to those of brachiosaurids. Convergently, similar values for gracility have been described in more derived taxa such as the somphospondylan Ligabuesaurus (Bonaparte et al. 2006; D'Emic 2012).

The proximal part of MDS-VPCR, 214 is asymmetrical as a result of its slight medial projection (Fig. 2a, c). In this character it differs from Turiasauria, a clade characterized by a marked medial projection of the proximal area (Royo-Torres et al. 2006). In anterior view, the proximal margin of MDS-VPCR, 214 is convex, and the proximomedial and proximolateral corners are slightly convex. MDSVPCR, 214 lacks a coracoid process. MDS-VPCR, 214 shares the rounded shape of the proximolateral corner with
Camarasaurus (Osborn and Mook 1921), brachiosaurids such as Brachiosaurus and Giraffatitan, and with non-titanosaurian somphospondylans such as Euhelopus or Chubutisaurus (Mannion et al. 2017); a rounded dorsolateral corner in the humerus is considered the plesiomorphic condition in non-somphospondylan titanosauriforms (Wilson 2002). A straight edge is considered a synapomorphy of Titanosauria (Mannion and Calvo 2011).

The proximal articular surface is distinctively rugose (Fig. 2e). The greatest thickness is found in the central part of the articular surface due to the great development of the humeral head in a posterior direction. Accordingly, a prominent humeral head projects from the posterior margin of the humerus in lateral view; the posterior face of the humeral head has a rugose articular surface that curves posterodistally. A posteriorly projected humeral head with a prominent process has been described in flagellicaudates such as Apatosaurus ajax and Suuwassea (Ostrom and McIntosh 1966; Upchurch et al. 2004; Harris 2004), in macronarians such as Haestasaurus (D'Emic 2012; Upchurch et al. 2015) and in titanosauriforms no titanosaurian (Wilson and Upchurch 2003; Bonaparte et al. 2006; Taylor 2009). As such, it is a character that is rather widespread in 
Neosauropoda. The anterior surface of the proximal area of MDS-VPCR, 214 is mediolaterally concave, forming a shallow depression with a semicircular outline and an irregular, fibrous surface (Fig. 3a). This depression is known as the coracobrachialis fossa (González Riga et al. 2015) and it corresponds to the coracobrachialis brevis muscle insertion (Borsuk-Białynicka 1977).

The posterior surface of the proximal area of the humerus is gently convex mediolaterally. Distal to the humeral head there is a slightly convex surface raised above the posterior surface of the humerus, running in a proximodistal direction and on both sides of the midline of the humerus (Figs. 2c and $3 \mathrm{c}$ ). This structure is not prolonged on the shaft and has not been described in other sauropods. In posterior view, there is a small, oval, somewhat rugose depression located between the above-described meseta and the lateral edge of the humerus (Fig. 3b, c), which could correspond to the latissimus dorsi insertion (Borsuk-Bialynicka 1977). Laterodistal to the process of the humeral head there is a small, elliptical depression with a striated surface (Fig. 3b, c), which is interpreted as the scapular deltoid insertion (Borsuk-Bialynicka 1977; Otero 2018). In lateral view, the proximolateral edge is prolonged as a vertically developed a rugose crest (Fig. 3b) in position posterior to the deltopectoral crest, where the insertion of the scapulohumeralis anterior is separated from the scapular deltoid insertion (sensu Borsuk-Bialynicka 1977; Otero 2018). In medial view, on the proximomedial edge of the humerus there is a rugose area (Fig. 3d) that would correspond to the subcoracoscapularis insertion (Borsuk-Bialynicka 1977), equivalent to the subscapularis and subcoracoideus of Otero (2018).

The deltopectoral crest is anteriorly oriented, is thickened at the lateral margin of the anterior surface of the humerus and it is relatively short in the proximodistal direction. Proximally, it begins close to the proximolateral corner and extends towards the midline of the shaft, in the proximal part of this, where it is less marked and relatively narrow (Fig. 2a, b). This more medial position of the distal part of
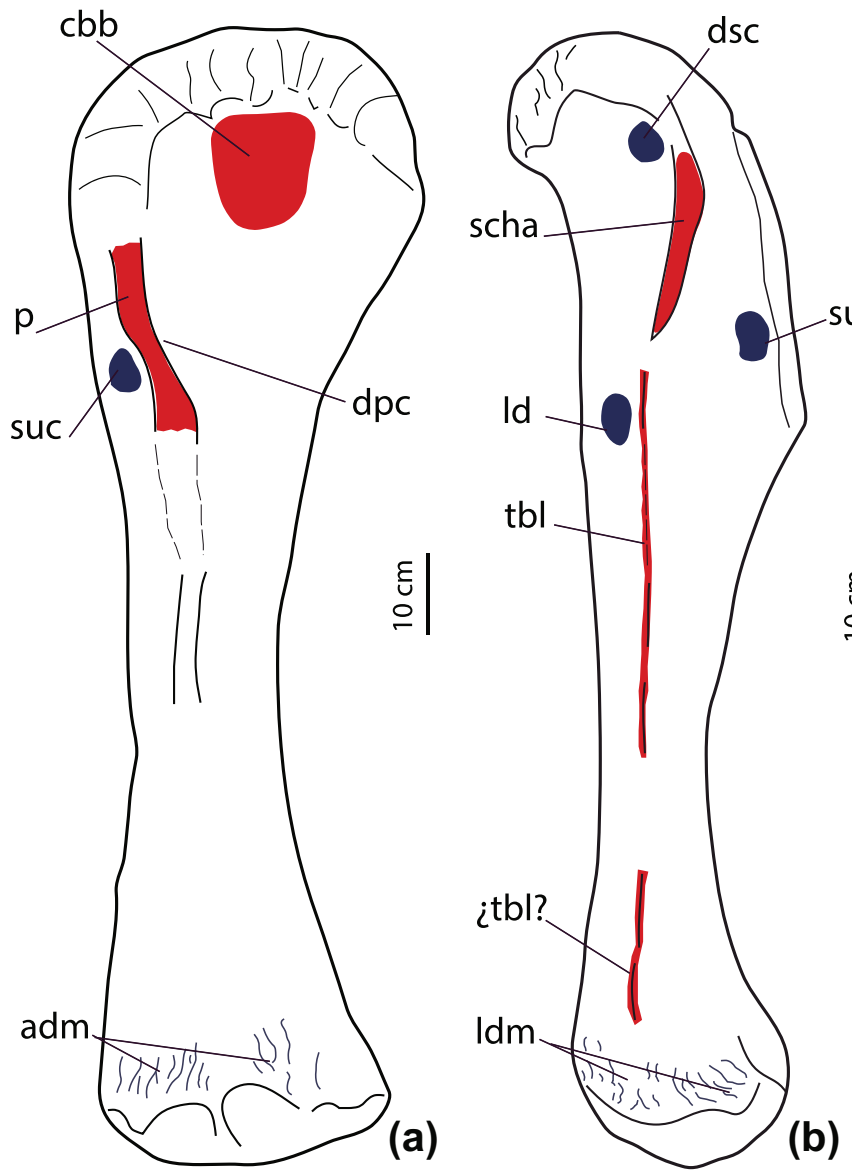

(b)

Fig. 3 Reconstruction of MDS-VPCR, 214 with anatomical elements and muscular insertions in $\mathbf{a}$ anterior, $\mathbf{b}$ lateral, $\mathbf{c}$ posterior and d medial view. $C b b$ coracobrachialis brevis, $d p c$ deltopectoral crest, $d s c$ scapular deltoid, af anconeal fossa, $h h$ humeral head, $l d$ latissimus dorsi, $a d m$ anterodistal muscular insertions, $l d m$ laterodistal muscu-
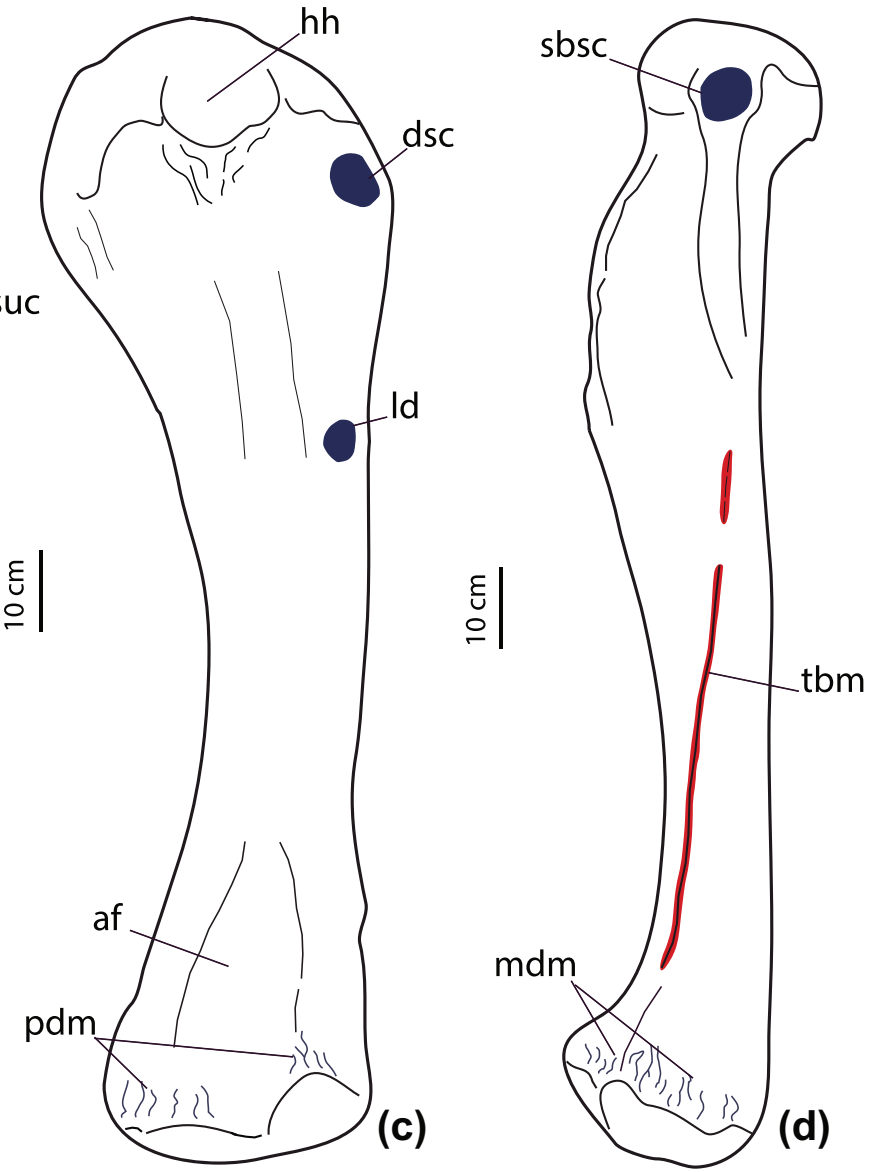

lar insertions, $m d m$ mediodistal muscular insertions, $p d m$ posterodistal muscular insertions, $p$ pectoralis, sbsc subcoracoscapularis, scha scapulohumeralis anterior, suc supracoracoideus, $t b l$ triceps brachii caput laterale, $\mathrm{tbm}$ triceps brachii caput medialis. Dark blue colour, muscular insertions; red colour, muscular origins 
the deltopectoral crest differs from a position restricted to the lateral margin, a plesiomorphic character in most sauropods and some titanosauriforms, and it is considered a derived character that it shares with certain other titanosauriforms (Upchurch et al. 2015). The scarce distal development of the deltopectoral crest of MDS-VPCR, 214 distinguishes it from Titanosauria, a clade in which the distal end is thickened. The turiasaurians share this character (Mateus et al. 2014). The total length of the deltopectoral crest is approximately $40 \%$ of the total length of the humerus, as occurs in the majority of sauropods, which differentiates it from the humerus of Turiasaurus and Galvesaurus, which reaches values of around 50\% or more (Barco 2009). In lateral view, the great anteroposterior expansion of the deltopectoral crest of MDS-VPCR, 214 can be made out, the apex of which is located in a proximal position. The distal half of the deltopectoral crest has a rugose surface where the pectoralis muscle inserts (Borsuk-Bialynicka 1977). The lateral surface of the deltopectoral crest forms a broad, shallow concavity in an anteroposterior direction.

The cross-section of the shaft of MDS-VPCR, 214 is elliptical, being wider mediolaterally than anteroposteriorly. Its eccentricity (ECC, Otero, 2010) is 1.33. The anterior surface of the shaft is flat mediolaterally, and the posterior surface is gently convex. In anterior view, the medial margin is concave and the lateral margin is practically straight, a derived character present in some titanosauriforms (Janensch 1961; Mateus et al. 2011; Upchurch et al. 2015; RoyoTorres et al. 2017), by contrast with the concave margin shown by diplodocoids, macronarians such Camarasaurus, titanosaurians such as Opisthocoelicaudia and Saltasaurus (Ostrom and McIntosh 1966; McIntosh 1990; Upchurch et al. 2015).

The shaft of MDS-VPCR, 214 has preserved several muscular insertions (Fig. 3). Along the lateral edge of the shaft there is a crest that crosses the proximal and medial parts of the shaft and gives rise to two projections in anterior view; this crest is interpreted as the insertion of the lateral branch of the muscle triceps brachii caput (Otero 2010) and the medial branch of the triceps brachii caput would insert in a continuous crest that runs along the medial edge of the shaft (Fig. 3b, d). In a more distal part of the lateral edge of the shaft there is another crest that presents two projections visible in anterior view, which could be continuations of the more proximal crest, although their position is very distal for the muscle triceps capiti humerales. Both the anterior surface and the posterior surface of the distal articular head show a marked, abundant rugosity that would be associated with the insertion of various muscles such as the brachialis, pronator teres, supinator and flexor muscles; likewise, on the medial and lateral surfaces extensive rugosity indicates the origin of flexor, abductor and extensor muscles (BorsukBialynicka 1977; Otero 2010).
The distal area of MDS-VPCR, 214 is gently convex in anterior view and is widened mediolaterally, a character that is more pronounced on the ulnar condyle in the distomedial corner of the humerus (Fig. 2a). Its anteromedial corner is convex and is without an entepicondylar process like that present in the macronarian Haestasaurus and in some titanosaurians (Upchurch et al. 2015). The anterior surface has radial and ulnar condyles, which are similar in degree of development, and between which there is a narrow groove that is prolonged on the articular end. These condyles are prominent and very rugose, and are slightly displaced towards the lateral half. The presence of separated condyles in the middle part of the anterior surface on the distal end is plesiomorphic for Sauropoda (character 83, D’Emic 2012) and is present in most members of this clade (Upchurch et al. 2015). The presence of a single undivided condyle is a feature of somphospondylans and most titanosaurians (D'Emic 2012; Upchurch et al. 2015).

The posterior surface of the distal part of the shaft presents a supracondylar or anconeal cubital fossa (Upchurch et al. 2015), delimited by two crests, one on its medial part and the other more prominent on its lateral part (Figs. 2c and $3 \mathrm{c}$ ). The depth of the anconeal fossa has a value of 0.07 , which is a very low value, similar to that estimated in Pelorosaurus and Mamenchisaurus, and less than 0.1, as occurs in many taxa in a variety of phylogenetic positions: Jobaria, Apatosaurus, Nigersaurus, Camarasaurus, Giraffatitan, Haestasaurus, Opisthocoelicaudia, Malawisaurus (Upchurch et al. 2015: Table 2, parameter Hafd).

The distal articular surface of MDS-VPCR, 214 is planoconvex in anterior view, with no division between the ulnar and radial condyles (Figs. 2a and 3a). The separate condyles at the distal humerus joint appear in Macronaria, and as a reversed character in saltasaurids (Barco 2009; Upchurch et al. 2015). The distal articular surface extends towards the anterior and posterior surfaces of the humerus; in this latter case, the projection is greater in the ulnar condyle than in the radial. This surface is very rugose, markedly so in its anterior half. In neosauropods such as Apatosaurus, Brachiosaurus and Suuwassea there is also a projection from the distal articular area in an anterior and/or posterior direction (Janensch 1961; Ostrom and McIntosh 1966; Harris 2006); in derived titanosaurs this projection is towards the anterior surface (character 163, Wilson 2002).

\subsection{Comparison with Iberian sauropods}

The humerus MDS-VPCR, 214 was compared with the humerus from other Iberian taxa of the Jurassic-Cretaceous boundary that have preserved it (Fig. 4). The taxa in question were: the turiasaurians Losillasaurus and Turiasaurus from the Tithonian-Berriasian of Spain (Casanovas et al. 2001; Royo-Torres et al. 2006) and Zby from the 
Kimmeridgian of Portugal (Mateus et al. 2014); the basal macronarians Lourinhasaurus from the upper Kimmeridgian-lower Tithonian of Portugal (Mocho et al. 2014) and Aragosaurus from the Berriasian of Spain (Sanz et al. 1987; Canudo et al. 2012; Aurell et al. 2016; Royo-Torres et al. 2017); the brachiosaurids Lusotitan from the Tithonian of Portugal (Antunes and Mateus, 2003; Mannion et al. 2013) and Galvesaurus from the Kimmeridgian of Spain (Barco et al. 2005; Barco, 2009; Pérez-Pueyo et al.
2019); and the basal titanosauriform assigned to cf. Duriatitan humerocristatus (Mocho et al. 2017).

The turiasaurian Losillasaurus has undifferentiated condyles in the distal part of the humerus (Fig. 4b), unlike MDS-VPCR, 214, which has condyles that can be distinguished on both the anterior and posterior surfaces. The deltopectoral crest in Losillasaurus is situated on the lateral margin of the humerus and occupies roughly $67 \%$ of the humerus, whereas in MDS-VPCR, 214 it only amounts to

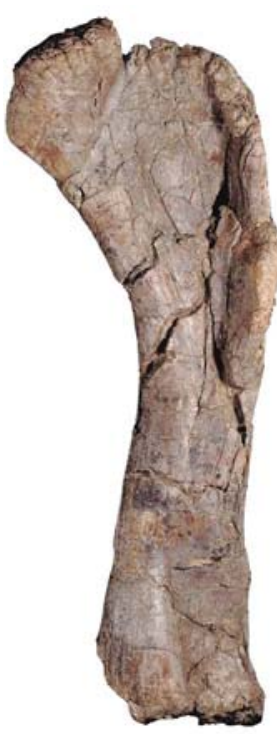

(a)

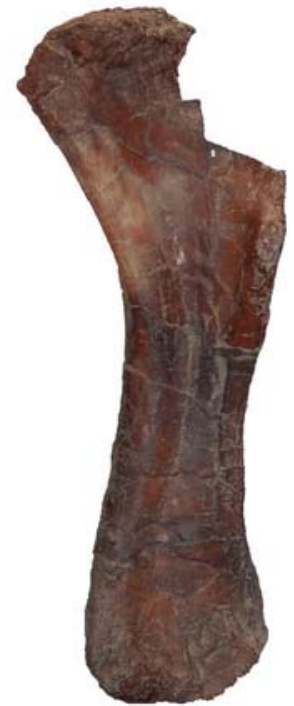

(b)

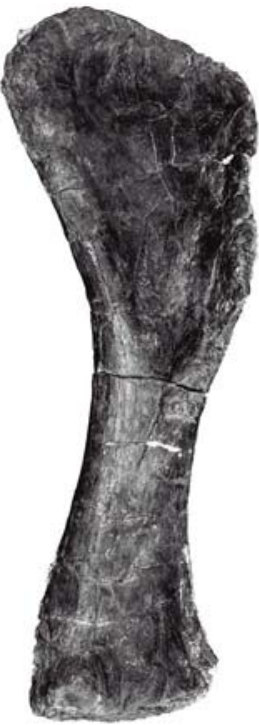

(c)

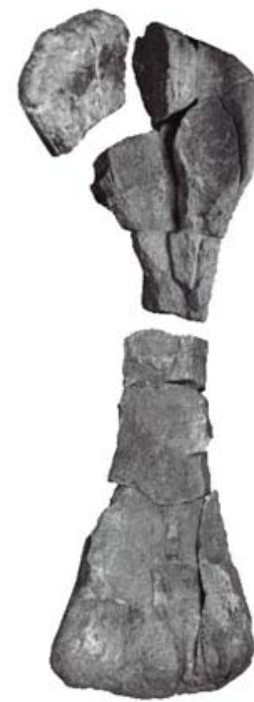

(d)

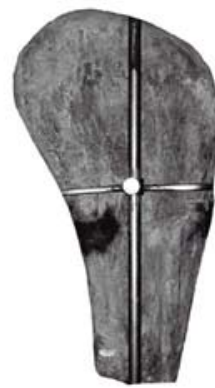

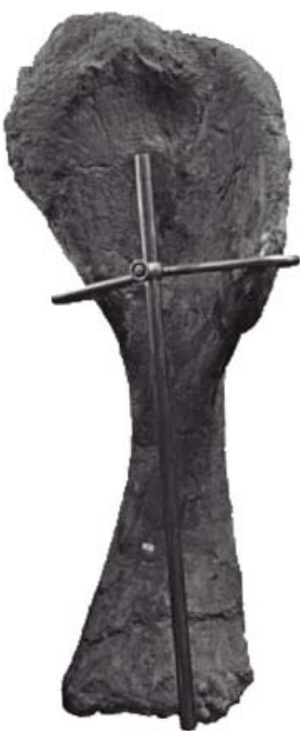

(f)

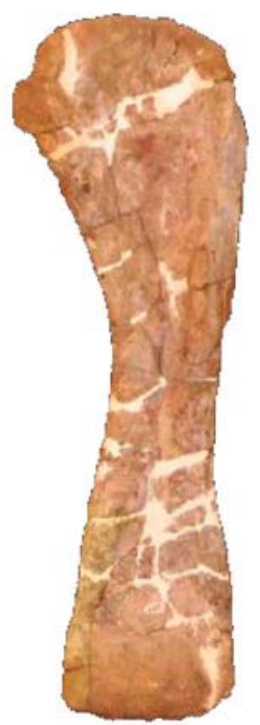

(g)

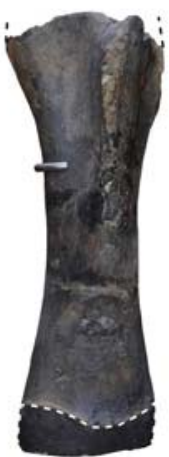

(h)

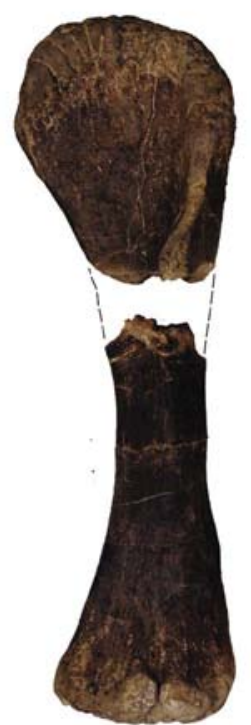

(i)
Fig. 4 Sauropod humeri of iberian taxons from the Jurassic-Cretaceous interval, in anterior view. a Turiasaurus, b Losillasaurus, c Zby, d Aragosaurus, e Lourinhasaurus, f Lusotitan, g Galvesaurus, h cf. Duriatitan humerocristatus (MG 4976), i MDS-VPCR, 214.
Modified from : Royo-Torres et al. (2006), Mateus et al. (2014), Royo-Torres et al. (2014), Mocho et al. (2014), Barco (2009), Mocho et al. (2016a, b) courtesy of J.L. Barco. The figures $\mathbf{c}, \mathbf{e}, \mathbf{g}$ and $\mathbf{h}$ are reversed for easy comparation 
$38 \%$ of the length. Moreover, the mediodistal edge of the humerus of Losillasaurus is rounded, and its distal edge in anterior view has a marked convexity (Casanovas et al. 2001), whereas MDS-VPCR, 214 has a mediodistal edge that is convex and medially prominent, and its distal edge is more gently convex. The values of the ratio of the mediolateral width of the shaft to the total length (MWD / L, Table 1) indicates ratio indicate that MDS-VPCR, 214 is more graceful than the humerus of Losillasaurus, being 0.25 and 0.18 (estimated), respectively.

MDS-VPCR, 214 shares with the humerus of Turiasaurus (Royo-Torres et al. 2006) a prominent deltopectoral crest and a straight lateral edge of the shaft (Fig. 4a). They differ in the marked medial projection of the proximal area of the humerus in Turiasaurus; the clear separation between the ulnar and radial condyles of Turiasaurus by contrast with the central position close to one another of the condyles in MDS-VPCR, 214; and the lesser mediolateral expansion of the distal end than the proximal end in Turiasaurus. The deltopectoral crest is positioned laterally in Turiasaurus, whereas in MDS-VPCR, 214, its distal area is situated towards the midline of the shaft. The outline of the distal edge of the humerus is straight in Turiasaurus and convex in MDS-VPCR, 214.

The humerus of the turiasaurian Zby (Mateus et al. 2014) is morphologically rather similar to that of Turiasaurus (Fig. 4c), differing from MDS-VPCR, 214 in the marked medial projection of the proximal area, the well-separated ulnar and radial condyles, the lateral position of the deltopectoral crest, and the development of a prominent swelling on the lateral margin of the posterior surface of the humerus.

The humerus of the basal macronarian Lourinhasaurus (Dantas et al. 1998; Mocho et al. 2014) has an expansion of the proximal area that is very marked compared to the distal area. The proximal edge in anterior view has an elevation or swelling in its medial half; the lateral edge of the shaft is concave; and the ulnar and radial condyles are well separated on the anterior surface of the distal area (Fig. 4e). In MDSVPCR, 214, the proximal and distal areas have more similar mediolateral expansions; the proximal edge of the proximal area shows a continuous convex development; the lateral edge of the shaft is straight and weakly concave; and the ulnar and radial condyles are close to one another, situated in the medial part of the anterodistal surface.

The humerus of the macronarian Aragosaurus (RoyoTorres et al. 2014) shares with MDS-VPCR, 214 a prominent process on the anterior surface of its distal area, which has ulnar and radial condyles at its midline, and there is a low medial projection of the proximal area of the humerus (Fig. 4d). The deltopectoral crest of Aragosaurus is not very marked, which distinguishes it from MDS-VPCR, 214; the humerus of Aragosaurus has high values for gracility: MLWPE/L $=0.29$, MLWDE/L $=0.3$ (estimated), with the lateral margin of the shaft concave, whereas MDS-VPCR, 214 is less gracile: $\mathrm{MLWPE} / \mathrm{L}=0.34, \mathrm{MLWDE} / \mathrm{L}=0.25$ and its lateral margin is straight.

The brachiosaurid Lusotitan only preserves the proximal halves of the left and of the right humerus (Fig. 4f) (Antunes and Mateus 2003; Mannion et al. 2013; Mocho et al. 2016b). Its humeral head is slightly displaced towards the medial half and projecting less towards the posterior than in MDSVPCR, 214, where the very prominent humeral head is situated at the midline of the proximal end. Likewise, in lateral view its deltopectoral crest is reduced, with a slighter anteroposterior development than in MDS-VPCR, 214.

Galvesaurus is a taxon that has been placed in various phylogenetic positions (Royo-Torres et al. 2006; Barco 2009; Mannion et al. 2013). Recently, however, it has been placed among basal Titanosauriformes, being included within Brachiosauridae (Pérez-Pueyo et al. 2019). The Galvesaurus humeri (Fig. 4g) and MDS-VPCR, 214 show similar values for gracility, as measured by the ratios MLWPE/L and MLWDE/L. The Galvesaurus humerus has an inconspicuous deltopectoral crest, developed on the lateral margin, unlike the crest of MDS-VPCR, 214, which is much more prominent towards the anterior, with the distal part occupying the central part of the anterior surface of the shaft. The lateral edge of the shaft is concave in Galvesaurus and practically straight in MDS-VPCR, 214. The anterior surface of the distal part of the Galvesaurus humerus lacks protrusions or projections; the mediodistal corner is straight; and the articular surface is delimited at the distal edge, a primitive character (Barco 2009). By contrast, the anterior surface in the distal part of MDS-VPCR, 214 has a protrusion on which the ulnar and radial condyles are situated; the mediodistal corner is convex and prominent; and the distal articular surface projects towards the anterior and posterior surfaces. The proximomedial edge of the Galvesaurus humerus CLH-1 has a crack that is lacking in MDS-VPCR, 214.

From the Kimmeridgian-Tithonian of Paria dos Frades (Portugal) comes the right humerus MG 4976 (Fig. 4h), attributed cf. Duriatitan humerocristatus (Mocho et al. 2017). The holotype of D. humerocristatus is only a fragmentary humerus of the Kimmeridgian of England initially attached to Cetiosaurus and recently used to define Duriatitan (Barrett et al. 2010). MG 4976 presents an autapomorphic character of Duriatitan, a ridge of proximal crystal development on the posterior view of the proximal end, located posterior to the deltopectoral ridge (Barret et al. 2010). However, Mocho et al. (2017) prefer to use open nomenclature taking into account the fragmentation of the Portuguese material and the English holotype. MDS-VPCR, 214 presents a general appearance similar to the two specimens assigned to Duratitan including the autapomorphic character proposed by Barrett et al. (2010). They also share the general slenderness of the bone, the scarce proximal 
development of the deltopectoral crest, the anterior orientation of the deltopectoral crest but occupying a more medial position distally and the shallow distal shallow anconeal fossa delimited by two soft ridges. MDS-VPCR, 214 and Duriatitan present differences such as the lateral edge of the diaphysis, practically straight in the MDS-VPCR, 214 and concave in Duriatitan, although in MG 4976 the concavity is less marked.

\section{Phylogenetic position of the sauropod from de Valdepalazuelos}

To undertake a preliminary phylogenetic analysis of the humerus MDS-VPCR, 214, we used the characters from the matrices developed by Wilson (2002), D'Emic (2012), Harris (2006), Whitlock (2011), Carballido and Sander (2014), Upchurch et al. (2015) and Carballido et al. (2017), which are identified by the number of the character in conjunction with the initials $\mathrm{W}, \mathrm{DE}, \mathrm{H}, \mathrm{WH}, \mathrm{CS}, \mathrm{U}$ and $\mathrm{C}$ respectively.

A- A series of primitive characters were recorded in the fossil from Torrelara:In the proximal area the proximolateral corner is convex (plesiomorphic in Sauropoda): 159W, 79DE, 225H, 102WH, 260CS, 308C.

B- On the anterior surface of the distal area there are two condylar projections: $258 \mathrm{CS}$.

C- The distal articular surface is straight; there is no condylar division: 164W, 84DE, 233H, 306C.

Likewise, various derived characters were identified in MDS-VPCR, 214:

A- Humerus not very robust, gracile: $78 \mathrm{DE}, 256 \mathrm{CS}$, 304C.

B- The distal portion of the deltopectoral crest is situated in the medial area of the shaft of the humerus: $228 \mathrm{H}$.

$\mathrm{C}$ - The deltopectoral crest is well developed and is very prominent: 160W, 227H, 253CS, 301C.

D- The cross-section of the shaft is elliptic: $170 \mathrm{~W}, 230 \mathrm{H}$, 161WH, 255CS, 303C.

E- The lateral margin of the shaft is straight: $163 \mathrm{WH}$, 259CS, 307C.

F- The distal articular surface extends towards the anterior and posterior: $163 \mathrm{~W}, 231 \mathrm{H}, 257 \mathrm{CS}, 305 \mathrm{C}$.

It has been suggested that a shallow anconeal fossa with lateral and medial crests, as possessed by MDS-VPCR,214, is a derived character, present in the majority of somphospondylans (Upchurch et al. 2015).

MDS-VPCR, 214 shares various characters with Titanosauriformes not titanosaurs, such as the gracility of the humerus, the prominent humeral head, and the distal part of the deltopectoral crest situated in the medial part of the shaft (Janensch 1961; Tidwell et al. 1999; Bonaparte et al. 2006; Harris 2006; Royo-Torres et al. 2017; Mannion et al. 2017). By the same token, MDS-VPCR, 214 has characters that it shares with Brachiosauridae, such as the elliptical section of the shaft, the straight lateral edge of the shaft, and the high gracility values (Taylor 2009; Tidwell et al. 1999; Royo-Torres et al. 2017; Mannion et al. 2013, 2017; PérezPueyo et al. 2019). Therefore MDS-VPCR, 214 is possibly a brachiosaurid titanosauriform, probably a basal taxon. In the description of MDS-VPCR it has shown the great morphological similarity to the holotype of Duriatitan, un this sense Barret et al. (2010) point out that Duriatitan is a member of Titanosauriformes, even earlier Naish and Martill (2007) place it in Brachiosauridae in the English humerus.

\section{Conclusions}

MDS-VPCR, 214 is a sauropod humerus with a different morphology from those so far described from the JurassicCretaceous transition of the Iberian Peninsula. It shares a general morphology and significant characters with the sauropods of Kimmeridgian Duriatitan humerocristatus holotype and the MG 4976 specimen assigned to cf. Duriatitan humerocristatus. Both specimens are fragmentary and of different age than MDS-VPCR, 214, so it is more appropriate to use the open nomenclature for MDS-VPCR, 214 (aff. Duriatitan) while waiting for new material from Valdepalazuelos-Tenadas del Carrascal site to clarify their relation with the English taxa.

The morphological characters of MDS-VPCR, 214 it situates as an early braching titanosauriform, possibly a brachiosaurid. Brachiosaurids are represented by basal forms in the Iberian Peninsula from the Kimmeridgian (Galvesaurus, Lusotitan). MDS-VPCR, 214 provides more evidences of the presence of a possible early braching Titanosauriformes in the Jurassic-Cretaceous transition of the Iberian Peninsula.

Acknowledgements The excavations at the site of ValdepalazuelosTenadas del Carrascal were financed by the Diputación de Burgos, with the collaboration of the Council of Torrelara and Fundación para el estudio de los Dinosaurios en Castilla y León. Special gratitude goes to the owners of the private land where the site is located, who made it possible to carry out all the work at the site, as well as for the Council of Quintanalara and the Asociación para el desarrollo de Tierra de Lara. The people who took part in the excavation did so voluntarily. Caterine Arias Riesgo, curator of the Museo de Dinosaurios de Salas de los Infantes, prepared and consolidated the humerus. The comments made by $\mathrm{P}$. Mocho and an anonymous reviewer greatly improved the quality of the manuscript. This study was subsidized in part by Project CGL2017-85038-P of the Spanish Ministerio de Economía y Competitividad-ERDF, as well as by the Aragón Regional Government ("grupo de Referencia Aragosaurus: reconstrucciones paleoambientales y recursos geológicos"). 


\section{References}

Alonso-Zarza, A. M. (2003). Palaeoenvironmental significance of palustrine carbonates and calcretes in the geological record. Earth-Science Reviews, 60(3-4), 261-298.

Antunes, M. T., \& Mateus, O. (2003). Dinosaurs of Portugal. Comptes Rendus Palevol, 2(1), 77-95. https://doi.org/10.016/S1631 -0683(03)00003-4.

Arribas, J., Alonso, A., Mas, R., Tortosa, A., Rodas, M., \& Barrenechea, J. F. (2003). Sandstone petrography of continental depositional sequences of an intraplate rift basin: western Cameros basin (north Spain). Journal of Sedimentary Research, 73(2), 309-327.

Aurell, M., Badenas, B., Canudo, J. I., Castanera, D., García Penas, A., \& Gasca, J. M. (2019). Kimmeridgian-Berriasian stratigraphy and sedimentary evolution of the central Iberian Rift System (NE Spain). Cretaceous Research, 103, 104153.

Aurell, M., Bádenas, B., Gasca, J. M., Canudo, J. I., Liesa, C., \& Soria, A. R. (2016). Stratigraphy and evolution of the Galve sub-basin (Spain) in the middle Tithonian-early Barremian: implications for the setting and age of some dinosaur fossil sites. Cretaceous Research, 65, 138-162.

Barco, J. L. (2009). Sistemática e implicaciones filogenéticas y paleobiogeográficas del saurópodo Galvesaurus herreroi (Formación Villar del Arzobispo, Galve, España). $\mathrm{PhD}$ thesis, Universidad de Zaragoza, pp. 1-389.

Barco, J. L., Canudo, J. I., Cuenca-Bescós, G., \& Ruiz-Omeñaca, J. I (2005). Un nuevo dinosaurio saurópodo Galvesaurus herreroi gen. nov., sp. nov. del tránsito Jurásico-Cretácico en Galve (Teruel, NE de España). Naturaleza Aragonesa, 15, 4-17.

Barrett, P. M., Benson, R. B. J., \& Upchurch, P. (2010). Dinosaurs of Dorset: Part II, the sauropod dinosaurs (Saurischia, Sauropoda) with additional comments on the theropods. Proceedings of the Dorset Natural History and Archaeological Society, 131, 113-126.

Bonaparte, J. F., González Riga, B., \& Apesteguía, S. (2006). Ligabuesaurus leanzai gen. et sp. nov. (Dinosauria, Sauropoda), a new titanosaur from the Lohan Cura Formation (Aptian, Lower Cretaceous) of Neuquén, Patagonia,\&nbsp;Argentina. Cretaceous Research, 27, 364-376.

Borsuk-Bialynicka, M. (1977). A new camarasaurid sauropod Opisthocoelicaudia skarzynskii gen. n., sp. n. from the Upper Cretaceous of Mongolia. Palaeontologica Polonica, 37, 5-64.

Campos-Soto, S., Benito, M. I., Cobos, A., Caus, E., Quijada, I. E., Suarez-Gonzalez, P., Mas, R., Royo-Torres, R., \& Alcalá, L. (2019). Revisiting the age and palaeoenvironments of the Upper Jurassic-Lower Cretaceous? dinosaur-bearing sedimentary record of eastern Spain: implications for Iberian palaeogeography. Journal of Ibeian Geology, 45, 471-510. https://doi.org/10.1007/s4151 3-019-00106-y.

Canudo, J. I., Barco, J. L., Castanera, D., Fernández-Baldor, T. F (2010). New record of an enigmatic sauropod in the JurassicCretaceous transition of the Iberian Peninsular (Spain). Paläontologische Zeitschrift, 84, 427-435.

Canudo, J. I., Gasca, J. M., Moreno, M., \& Aurell, M. (2012). New information about the stratigraphic position and age of the sauropod Aragosaurus ischiaticus from the Early Cretaceous of the Iberian Peninsula. Geological Magazine, 149(2), 252-263.

Canudo, J. I., Ruiz-Omeñaca, J. I., Barco, J. L., García-Ramos, J. C., \& Piñuela, L. (2006). The discovery of a singular fauna: the sauropods from the Late Jurassic and earliest Cretaceous of Spain. Journal of Vertebrate Paleontology, 26(3), 47A-47A.

Carballido, J., Sander, M., P (2014). Postcranial axial skeleton of Europasaurus holgeri (Dinosauria, Sauropoda) from the Upper Jurassic of Germany: implications for sauropod ontogeny and phylogenetic relationships of basal Macronaria. Journal of Systematic Palaeontology, 12(3), 335-387.
Carballido, J. L., Pol, D., Otero, A., Cerda, I. A., Salgado, L., \& Garrido, A. C. (2017). A new giant titanosaur sheds light on body mass evolution among sauropod dinosaurs. Proceedings of the Royal Society B, 284, 20171219.

Casanovas, M. L., Santafé, J. V., \& Sanz, J. (2001). Losillasaurus giganteus, un nuevo saurópodo del tránsito Jurásico - Cretácico de la cuenca de "Los Serranos" (Valencia, España). Paleontologia i Evolució, 32-33, 99-122.

Castanera, D., Pascual, C., Canudo, J. I., \& Barco, J. L. (2018). Bringing together research, geoconservation and reaching a broad public in the form of a geotourism project: the Ichnite Route of Soria. Geoheritage, 10, 393-403.

Clemente, P. (2010). Review of the Upper Jurassic-Lower Cretaceous stratigraphy in Western Cameros basin, Northern Spain. Revista de la Sociedad Geológica de España, 23(3-4), 101-143.

Clemente, P., \& Pérez Arlucea, M. (1993). Depositional architecture of the Cuerda del Pozo Formation, Lower Cretaceous of the extensional Cameros Basin, north-central Spain. Journal of Sedimentary Petrology, 63(3), 437-452.

Dantas, P., Sanz, J. L., Silva, C. M., Ortega, F., Santos, V. F., \& Cachão, M. (1998). Lourinhasaurus n. gen. novo dinossáurio saurópode do Jurássico superior (Kimmeridgiano superior - Titoniano inferior) de Portugal. Actas do V Congresso de Geologia, 84, 91-94.

D'Emic, M. D. (2012). The early evolution of titanosauriform sauropod dinosaurs. Zoological Journal of the Linnean Society, 166, 624-671.

González Riga, BJ., Ortiz David, L.D., Tomaselli, M.B., dos Anjos Candeiro, C.R., Coria, J.P., \& Prámparo, M. (2015). Sauropod and theropod dinosaur tracks from the Upper Cretaceous of Mendoza (Argentina): Trackmakers and anatomical evidences. Journal of South American Earth Sciences, 61, 134-141. https://doi. org/10.1016/j.jsames.2014.11.006.

Harris, J. D. (2004). Confusing dinosaurs with mammals: tetrapod phylogenetics and anatomical terminology in the world of homology. The Anatomical Record, 281, 1240-1246.

Harris, J. D. (2006). The axial skeleton of the dinosaur Suuwassea emilieae (Sauropoda: Flagellicaudata) from the Upper Jurassic Morrison Formation of Montana, USA. Palaeontology, 49(5), $1091-1121$.

Harris, J. D. (2007). The appendicular skeleton of Suuwassea emilieae (Sauropoda: Flagellicaudata) from the Upper Jurassic Morrison Formation of Montana (USA). Geobios, 40, 501-522.

Hock Hocknull, S. A., White, M. A., Tischler, T. R., Cook, A. G., Calleja, N. D., \& Sloan, T. (2009). New mid-cretaceous (Latest Albian) dinosaurs from Winton, Queensland,\&nbsp; Australia. Plos One, 4(7), e6190.

Huerta, P., \& Armenteros, I. (2005). Calcrete and palustrine assemblages on a distal alluvial-floodplain: A response to local subsidence (Miocene of the Duero basin, Spain). Sedimentary Geology, $177(3-4), 253-270$

Janensch, W. (1961). Die Gliedmaszen und Gliedmaszengürtel der Sauropoden der Tendaguru-schichten. Palaeontographica, 7(2), 178-233.

Kullberg, J. C., Rocha, R. C., Soares, A. F., Rey, J., Terrinha, Callapez, \& P., Martins, L., L. (2006). A Bacia Lusitaniana: estratigrafia, paleogeográfica e tectónica. In R. Dias, A. Araújo, P. Terrinha, \& J. C. Kullberg (Eds.), Geologia de Portugal no contexto da Ibérica (pp. 317-368). Évora: Universidade de Évora.

Mannion, P. D., Allain, R., \& Moine, O. (2017). The earliest known titanosauriform sauropod dinosaur and the evolution of Brachiosauridae. PeerJ, 5, e3217.

Mannion, P. D., \& Calvo, J. O. (2011). Anatomy of the basal titanosaur (Dinosauria, Sauropoda) Andesaurus delgadoi from the midCretaceous (Albian-early Cenomanian) Río Limay Formation, Neuquén Province, Argentina: implications titanosaur systematics. Zoological Journal of the Linnean Society, 163, 155-181. 
Mannion, P. D., Upchurch, P., Barnes, R. N., \& Mateus, O. (2013). Osteology of the Late Jurassic Portuguese sauropod dinosaur Lusotitan atalaiensis (Macronaria) and the evolutionary history of basal titanosauriformes. Zoological Journal of the Linnean Society, 168, 98-206.

Martín-Closas, C., Millán, A., A (1998). Estratigrafía y bioestratigrafía (Charophyta) del Cretácico inferior en el sector occidental de la Cuenca de Cameros (Cordillera Ibérica). Revista de la Sociedad Geológica de España, 11(3-4), 253-270.

Mas, R., Arribas, M. E., Gonzalez-Acebron, L., Quijada, I. M., Campos-Soto, S., Suarez-Gonzalez, P., Sacristan-Horcajada, S., Arribas, J., Benito, M. I., Perez-Garrido, C., \& Alonso, A. (2019). Coastal wetlands as markers of transgression in proximal extensional systems (Berriasian, W Cameros Basin, Spain) Journal of Iberian Geology, 45, 1-27. https://doi.org/10.1007/ s41513-018-0086-y.

Mateus, O., Jacobs, L. L., Schulp, A., Polcyn, M. J., Tavares, T. S., \& Buta Neto, A. (2011). Angolatitan adamastor, a new sauropod dinosaur and the first record from Angola. Anais da Academia Brasileira de Ciências, 83(1), 1-13.

Mateus, O., Mannion, P. D., \& Uchurch, P. (2014). Zby atlanticus, a new turiasaurian sauropod (Dinosauria, Eusauropoda) from the Late Jurassic of Portugal. Journal of Vertebrate Paleontology, 43(3), 618-634.

McIntosh, J. S. 1990. Sauropoda. The Dinosauria, D. B. Weishampel, P. D. Dodson, H. Osmolska (eds.), University of California Press, Berkeley. D. B. Weishampel \& P. Dodson, H. Osmólska. University of California Press, 345-390.

Mocho, P., Royo-Torres, R., Malafaia, E., Escaso, F., \& Ortega, F. (2016a). Systematic review of Late Jurassic sauropods from the Museu Geológico collections (Lisboa, Portugal). Journal of Iberian Geology, 42(2), 227-250. https://doi.org/10.5209/rev_ JIGE.2016.v42.n2.52177.

Mocho, P., Royo-Torres, R., Malafaia, E., Escaso, F., \& Ortega, F. (2017). Sauropod tooth morphotypes from the Upper Jurassic of the Lusitanian Basin (Portugal). Papers in Palaeontology, 3(2), 259-295.

Mocho, P., Royo-Torres, R., \& Ortega, F. (2014). Phylogenetic reassessment of Lourinhasaurus alenquerensis, a basal Macronaria (Sauropoda) from the Upper Jurassic of Portugal. Zoological Journal of the Linnean Society, 170(4), 875-916.

Mocho, P., Royo-Torres, R., \& Ortega, F. (2016b). New data of the Portuguese brachiosaurid Lusotitan atalaiensis (Sobral Formation, Upper Jurassic). Historical Biology. https://doi.org/10.1080/08912 963.2016.1247447.

Mocho, P., Royo-Torres, R., \& Ortega, F. (2019). A new macronarian sauropod from the Upper Jurassic of Portugal. Journal of Vertebrate Paleontology, 39, e1578782.

Naish, D., \& Martill, D. M. (2007). Dinosaurs of Great Britain and the role of the Geological Society of London in their discovery: basal Dinosauria and Saurischia. Journal of the Geological Society, 164(3), 493-510. https://doi.org/10.1144/0016-76492006-032.

Osborn, H. F., \& Mook, C. C. (1921). Camarasaurus, Amphicoelias and other sauropods of Cope. Memoirs of the American Museum of Natural History New Series, 3, 247-387.

Ostrom, J. H., \& McIntosh, J. S. (1966). Marsh's dinosaurs. The collections from Como Bluff (Yale University Press. 1-388). New Haven: Yale University Press.

Otero, A. (2010). The appendicular skeleton of Neuquensaurus, a Late Cretaceous saltasaurine sauropod from Patagonia, Argentina. Acta Palaeontologica Polonica, 55(3), 399-426.

Otero, A. (2018). Forelimb musculature and osteological correlates in Sauropodomorpha (Dinosauria, Saurischia). Plos One, 13(7), e0198988.

Pérez-Pueyo, M., Moreno-Azanza, M., Barco, J. L., \& Canudo, J. I. (2019). New contributions to the phylogenetic position of the sauropod Galvesaurus herreroi from the Tithonian (Jurassic) of Spain (Teruel). Boletín Geológico y Minero, 130(3), 375-392.

Platt, N. H. (1986). Sedimentology and tectonics of the western Cameros basin. Province of Burgos, Northern Spain. PhD Thesis, University of Oxford, pp. 1-125.

Platt, N. H. (1989). Lacustrine Carbonates and Pedogenesis - Sedimentology and Origin of Palustrine Deposits from the Early Cretaceous Rupelo Formation, W Cameros Basin, N Spain. Sedimentology, 36(4), 665-684

Royo-Torres, R., Cobos, A., \& Alcalá, L. (2006). A giant european dinosaur and a new sauropod clade. Science, 314, 1925-1927.

Royo-Torres, R., Cobos, A., Luque, L., Aberasturi, A., Espílez, E., \& Fierro, I. (2009). High european sauropod dinosaur diversity during Jurassic-Cretaceous transition in Riodeva (Teruel, Spain). Palaeontology, 5(2), 1009-1027.

Royo-Torres, R., Upchurch, P., Mannion, P., Mas, R., Cobos, A., \& Gasco, F. (2014). The anatomy, phylogenetic relationships, and stratigraphic position of the Tithonian-Berriasian Spanish sauropod dinosaur Aragosaurus ischiaticus. Zoological Journal of the Linnean Society, 171(3), 623-655.

Royo-Torres, R., Fuentes, C., Meijide, M., Meijide-Fuentes, F., \& Meijide-Fuentes, M. (2017). A new Brachiosauridae Sauropod dinosaur from the lower Cretaceous of Europe (Soria Province, Spain). Cretaceous Research, 80, 38-55. https://doi.org/10.1016/j. cretres.2017.08.012.

Sacristán-Horcajada, S., Mas, R., \& Arribas, M. E. (2015). Early SynRift Evolution In the West Cameros Basin (Upper Jurassic, NW Iberian Range), Spain. Journal of Sedimentary Research, 85(7), 794-819.

Sanz, J. L., Buscalioni, A. D., Casanovas, M. L., \& Santafé, J. V. (1987). Dinosaurios del Cretácico Inferior de Galve (Teruel, España). Estudios geológicos, volumen extraordinario Galve Tremp, pp. 45-64.

Schudack, U., \& Schudack, M. (2009). Ostracod biostratigraphy in the Lower Cretaceous of the Iberian chain (eastern Spain). Journal of Iberian Geology, 35(2), 141-168.

Taylor, M. P. (2009). A re-evaluation of Brachiosaurus altithorax Riggs 1903 (Dinosauria, Sauropoda) and its generic separation from Giraffatitan brancai (Janensch 1914). Journal of Vertebrate Paleontology, 29(3), 787-806.

Tidwell, V., Carpenter, K., \& Brooks, W. (1999). New sauropod from the Lower Cretaceous of Utah, USA. Oryctos, 2(21), 21-37.

Torcida Fernández-Baldor, F., Díaz-Martínez, I., Huerta, P., ContrerasIzquierdo, R., Montero, I., Huerta, L. A. M. D. (2012). Estudio previo del yacimiento de icnitas de dinosaurios de Las Sereas (Cuenca de Cameros, Jurásico Superior-Cretácico Inferior). Actas de V Jornadas Internacionales sobre Paleontología de Dinosaurios y su Entorno, pp. 197-204.

Upchurch, P., Mannion, P. D., \& Taylor, M. P. (2015). The anatomy and phylogenetic relationships of "Pelorosaurus" becklesii (Neosauropoda, Macronaria) from the Early Cretaceous of England. Plos One, 10(6), e0125819.

Upchurch, P., Tomida, Y., \& Barrett, P. M. (2004). A new specimen of Apatosaurus ajax (Sauropoda: Diplodocidae) from the Morrison Formation (Upper Jurassic) of Wyoming, USA. National Science Museum of Tokyo Monographs, 26, 1-107.

Whitlock, J. A. (2011). A phylogenetic analysis of Diplodocoidea (Saurischia: Sauropoda). Zoological Journal of the Linnean Society, 161(4), 872-915.

Wilson, J. A. (2002). Sauropod dinosaur phylogeny: critique and cladistic analysis. Zoological Journal of the Linnean Society, 136(2), 215-275.

Wilson, J. A., \& Upchurch, P. (2003). A revision of Titanosaurus Lydekker (Dinosauria-Sauropoda), the first dinosaur genus with "gondwanan" distribution. Journal of Systematic Palaeontology, l(3), 125-160. 